
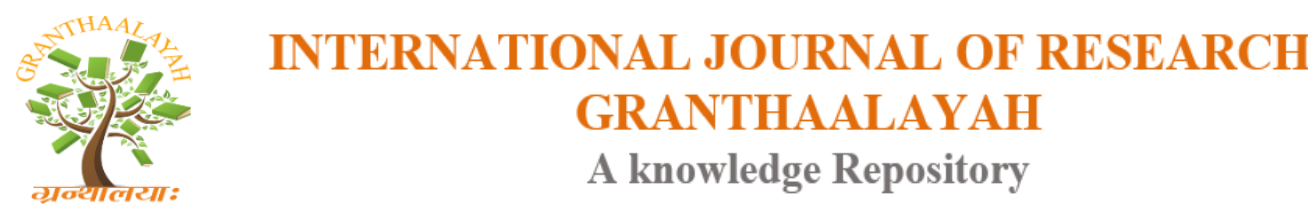

Science

\title{
PERFORMANCE OF A TANGENTIALLY FIRED BOILER IN A THERMAL POWER PLANT
}

\author{
Koilada Abhinash ${ }^{1}$, P.S. Kishore ${ }^{2}$ \\ ${ }^{1}$ M.Tech., Student, Department of Mechanical Engineering, College of Engineering (A), Andhra \\ University, Visakhapatnam, Andhra Pradesh, India \\ ${ }^{2}$ Ph.D., Professor, Department of Mechanical Engineering, College of Engineering (A), Andhra \\ University, Visakhapatnam, Andhra Pradesh, India
}

\begin{abstract}
The most effective method for producing intense turbulence is by the impingement of one flame on another. This action is secured through the use of burners located in each of the four corners of the furnace. The burner nozzles are so directed that the streams of coal and air are projected along a line tangent to a small circle, lying in a horizontal plane, at the centre of the furnace. A scrubbing action is present which assures contact between the combustible and oxygen, thus promoting rapid combustion and reducing carbon loss. The experimental results of this study can be summarized as the use of tangentially fired boiler which increase splendid air-fuel mixture and pulverized coal is entrained in Primary Air (PA), and in-addition to that the Secondary Air (SA) is also projected towards the mill, finally a rotating "FIRE BALL" is formed.

The present work analysis is carried out on Tangentially Fired Boiler by considering heat input through four burners. The heat output is determined by considering various losses from the boiler that is loss due to dry gas, loss due to moisture, loss due to $\mathrm{H} 2$ for combustion, heat loss due to combustile and refuse and losses due to radiation etc. In addition heat absorbed by economizer, boilers, superheater and reheater are studied, thus finally the net heat absorbed and thermal efficiency of tangentially fired boiler are determined.

Graphs are drawn to evaluate the various effects of heat input on output parameters in the boiler. Sankey diagrams are drawn to show the performance in the boiler. The values calculated are put and shown as tables in Appendix.
\end{abstract}

Keywords: Tangential Burner; Heat Supplier; Heat Losses; Work Input; Work Output and Efficiency.

Cite This Article: Koilada Abhinash, P.S. Kishore. (2018). "PERFORMANCE OF A TANGENTIALLY FIRED BOILER IN A THERMAL POWER PLANT.” International Journal of Research - Granthaalayah, 6(5), 391-406. 10.29121/granthaalayah.v6.i5.2018.1467.

\section{Introduction}

Power generation has become a vital role in every segment of present world. To produce that much of power the tangentially fired boiler is accessible by varying the major influencing factors such 
as the inlet temperature, local heat release, practice size distribution, supply of primary and secondary air mixture. This scenario helps to increase the heat input and efficiency of the power plant.

The present concept describes the operating principles and heat input procedure of corner type burners. These are also called tangential type burners because here pulverized coal and air are injected tangentially into an imaginary circle in the centre from four corners of the furnace.

Tangentially firing is a method of firing a fuel to heat air in thermal power stations. The flame envelope rotates ensuring thorough mixing within the furnace, providing complete combustion and uniform heat distribution.

\subsection{Tangential Fired Burners}

Application of burners is considered in the corners of the furnace and passage of horizontal streams of air and fuel tangent to an imaginary circle in the centre of the furnace. This results in intense turbulence and thorough mixing of fuel and air. All the fuel and air nozzles can be titled $24^{\circ}$.

Tangentially firing can also be classified according to the mode of distribution of primary and secondary air patterns in the burners. These are described below.

- Opposed tangential arrangement

- Burners with side secondary air

- Burners with peripheral air

- Burners with sandwich air

Offen and Kesserlring [1] in their paper analyzed the studies into the effects of operating conditions in a tangential fired furnace using $3 \mathrm{~d}$ combustor model to determine temperature, velocity and thermal characteristics. They also proposed information about the Primary Air and Secondary Air inlet temperature, pressure, perfect air-fuel ratio in the combustion process.

Fande and Joshi [2] in their paper studied the particle trajectories that are used to identify the causes of operational problems such as fouling on burners and temperatures achieved in various parts of boiler during the combustion process.

Silva [3] worked about combustion technique can be applied for hard coal, oil, biomass, dust and natural gas in combination. The central vortex in the combustion reactor can be controlled by the burners in operation in mode enables low stoichiometry combustion to take place in furnace centre in the primary combustion zone.

Piper et al. [4] have explained that to get higher combustion efficiency, the major influencing factors such as the particle size distribution, local heat release local oxygen concentration, kinetic parameters for oxidation should be considered.

Lakshmi \& Kishore [5] have addressed the thermal efficiency of purverised fuel boiler in a power plant to increase its heat input parameters. 
Ferreir and carlos [6] have explained in detail about the temperature of the heat input and fields which were obtained from the solution of the conversation equation of mass, momentum and energy of the turbulence model. This theory has also given the splendid work on the Heat input and other characteristics.

Haiying and Gregory [7] in their book proposed the working and basic details on boilers and pulverized coal burners. This scenario also describes the operating principles and design procedures of corner - type burners because here pulverized coal and air are injected tangentially into an imaginary circle in the centre from the four corners of the furnace.

Cheng - dong et al. [8] in their paper point out towards the locating and estimating air emissions from sources of polycyclic organic matter. This theory also describes the irrelevant ratio of air fuel mixture causes excess expel of emissions such as $\mathrm{No}_{x}, \mathrm{Co}_{2}$, etc. from the tangentially fired boiler.

Chattopadhyay et al. [9] in their book examined that the efficiency of steam cycle can be immersed by increasing the temperature and decreasing the pressure. In their paper explained thermal power plant consists of different machinery, in which the efficiency plays a major role. To increase the efficiency of plant release of excess emissions from output should be reduced and combustion should be increased, therefore perfect output can be achieved.

Kishore \& Praveen [10] have given the information above effectiveness of rotary air pre-heater in a thermal power plant to increase its efficiency.

Rao [11] in his book explained the performance and combustion properties of boilers and burners. He addressed various methods like heat input, excess air coefficient and coal input, which are used to increase the efficiency of the boiler and in further cases it also describes to decrease the emissions into the environment and further decrease in pollution.

Justin et al. [12] in their book analyzed the combustion reaction, its stages and the beneficial constituents producing good amount of output. In their book addressed the performance and combustion properties of boilers and burners and also investigated the effect of inlet temperatures of ambient air and types of coal and their combustion properties in a solid state and pulverized state in the tangentially fire tube boiler of thermal power plant.

Rajput [13] in his book proposed on mixed fuel fired boilers indicate that no emissions levels increase as the percentage of coal in the coal-air or coal-gas mixture increased.

Thomas and Mahallawy [14] have explained the $\mathrm{Co}_{2}$ emissions released from conventional fossil fuel power plant during combustion process. The emissions of $\mathrm{Co}_{2}, \mathrm{No}_{\mathrm{x}}$ etc. can be reduced by appending excess air into the boilers.

Robert et al. [15] in their paper overviewed on the handling a wide variety of coals, ranging from bituminous to lignite, is an environmentally acceptable way, which is attractive for use in power generation. 
Abhinash [16] estimated the Evaluation of Heat-Input and Efficiency of tangentially fired boiler in a thermal power plant to undergo complete combustion in boiler.

\section{Description and Working of TFB}

The tangentially fired boiler is based on the concept of a single flame zone within the furnace. The fuel-air mixture in a tangentially fired boiler projects from the four corners of the furnace along a line tangential to an imaginary cylinder located along the furnace centerline. When coal is used as the fuel, the coal is pulverized and entrained in primary air, and fired in suspension. As fuel and air are fed to the burners, a rotation "fire ball" is formed, which control the furnace exit gas temperature and provide steam temperature control during variation in load.

Tangential firing gives a swirling action to the fuel which increases the residence time of fuel into the furnace and also increases turbulence. Thus tangential firing promotes the coal input range between $10000 \mathrm{~kg} / \mathrm{hr}$ and $11452 \mathrm{~kg} / \mathrm{hr}$ with primary air impended to the furnace from the burner, in addition to that secondary air possess the increase of ignition in the furnace and participate in the maximization of combustion efficiency.

In the combustion process there will be release of losses such as loss due to radiation, loss due to dry gas, loss due to combustile and refuse. Finally, we can obtain the total heat output of 16589.61 $\mathrm{kJ} / \mathrm{hr}$ with the heat losses of $1757.01 \mathrm{~kJ} / \mathrm{hr}$ for given heat input of $18085.21 \mathrm{~kJ} / \mathrm{hr}$. The overview can be governed by factors like rationalization of Combustion, rationalization of Heat input and lastly prevention of heat losses.

The tangentially fired boiler is used as a large and medium size coal fired boilers. In these boilers the burners plays vital role in the impact of heat and follows the efficiency.

The primary air jet carries the pulverized coal and entrains hot gases from its vicinity, while the secondary air is injected in tangential to the furnace centre, which further processed towards the heat input.

The practical tangentially fired boiler working in the National Thermal Power Corporation limited which is located in Vijayawada, Andhra Pradesh, India. Its capacity is designed to generate $9700 \mathrm{~kJ} / \mathrm{kg}$. Due to some losses its overall heat input is $8108 \mathrm{~kJ} / \mathrm{kg}$. In this work, total heat input of NTPC power plant is designed by changing the coal input so that increasing the coal input in the tangential burner will leads to maximize the heat input and further leads to increase in heat output from the boiler. This will increase the burning capacity of the burner and further increases the temperature, so that heat input increases in this operation and better effectiveness is obtained. In further case the total heat input is transmitted to the components of economizer, boiler, superheater and reheater which further absorbs more heat input and gets converted in the participation of increase in the efficiency of the tangentially fired boiler. 


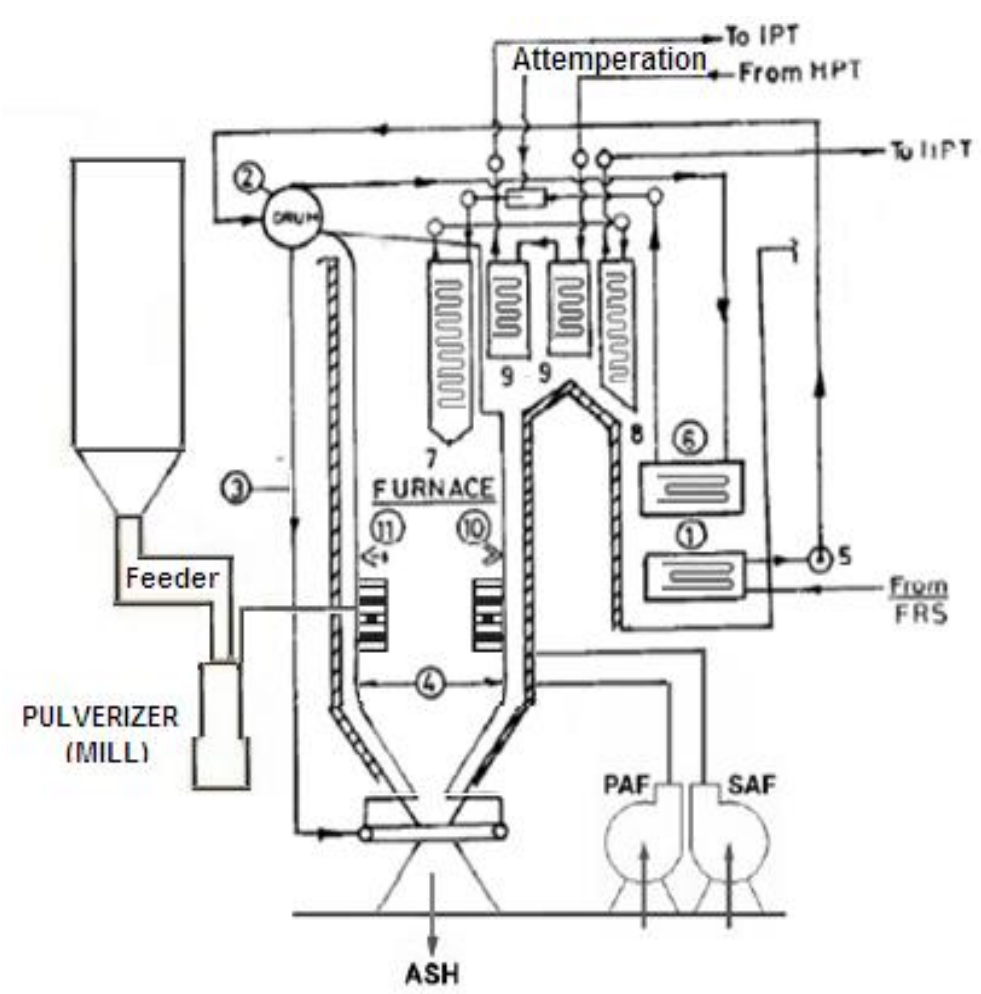

Figure 1: Layout of Tangentially Fired Boiler

\section{Components}

1) Economizer

2) Boiler drum

3) Down comers

4) Water wall

5) Pump

6) Primary superheater.

7) Plater superheater

8) Final superheater

9) Reheater

10) Burners

11) Igniters

PAF Primary Air Fan

SAF Secondary Air Fan

\section{Tangential Firing}

1) Tangential firing is a method of firing fuel to heat air in thermal power station, in which flame rotates ensuring through mixing within the furnace.

2) This action is secured through the use of burners located in each of the four corners of the furnace, which provides complete combustion and uniform heat distribution. With this tangential firing combustion is extremely rapid and short flame length results throughout the operation. 


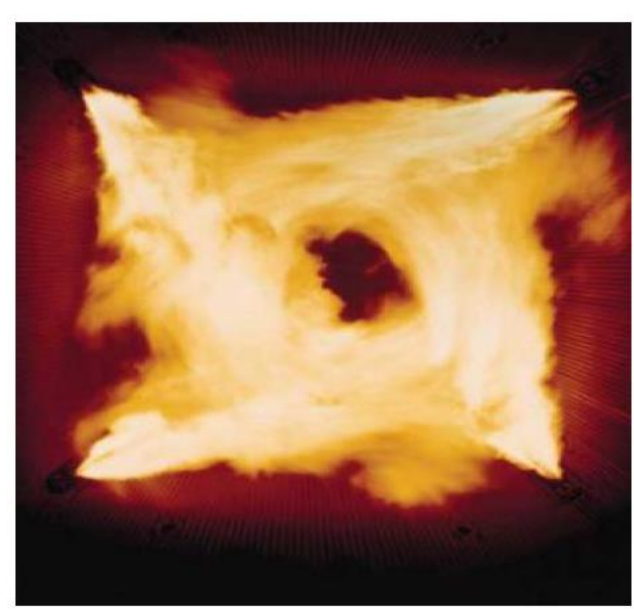

Figure 2: Burning in a Fireball System

\section{Deviation of the Jet}

Typical deviations of the air jet from geometrical axis of the burner, which is tangent to the imaginary firing circle. There are two main reasons for this deviation. First, the spiraling air flow collides with the jet, laterally deviating the jet. Second, the jet injected from the burner into the confined furnace space entrains peripheral gas. Results show that the diameter of the actual air flow circle, $\mathrm{d}_{\mathrm{y}}$, is about 2.5 to 4 times that of designed firing circle, $\mathrm{d}_{0}$. But if the diameter of imaginary circle and height-width ratio of burners are too large, serious slagging may occur because the air flow deviates excessively towards the furnace wall.

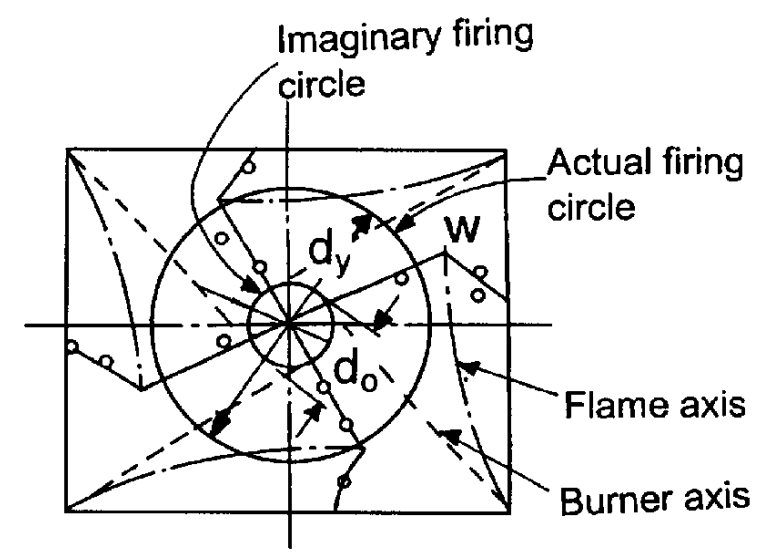

Figure 3: Tangential Velocity Distribution in a Tangential Boiler

\section{Flame Stability}

The stabilization of the flame under all operating conditions without an external support is an essential condition for well designed burners. The following measures can be taken to enhance flame stabilization.

- Increase the number of primary air nozzles to enlarge the contact area of primary air with the hot gas in the furnace. 
- Introduce a low volume of secondary air but at a high velocity around the primary air. The high speed jet curtain secondary air can efficiently entrain hot gas in the furnace and mix it with primary air.

- Increase the distance between the nozzles for the primary and secondary air, so that fuel with the primary air will ignite well before it mixes with secondary air.

\section{Secondary Air}

The secondary air in tangential firing pulverized coal burners may be roughly divided into upper, Central and bottom air. The upper secondary jet will be inclined $0-12^{\circ}$ downward. Central secondary air registers with an indication about $5-15^{\circ}$ downward, where as bottom secondary air is relatively low, about $15-26 \%$ of total secondary air.

\section{Analysis of TFB}

\section{Analysis of the Problem}

From the Tangentially Fired Boiler different losses are obtained. The losses are loss due to dry gas, loss due to combustile and refuse, loss due to $\mathrm{H}_{2}$ for combustion, and loss due to radiation. The calculations of various losses in boiler are discusses below. In addition to this heat input, heat output and efficiency in a tangentially fired boiler are also calculated.

\section{Simple Boiler}

Total heat input or calorific value $(\mathrm{kJ} / \mathrm{kg})$

\section{Heat Absorbed by the Boiler}

$\mathrm{q}_{0}=\mathrm{m}_{\mathrm{a}} \mathrm{x}\left(\mathrm{h}-\mathrm{h}_{\mathrm{f}}\right)$

Where,

$$
\mathrm{m}_{\mathrm{a}}=\frac{\text { Mass of water evaporated }}{\text { Quantity of coal consumed }}
$$

$$
\begin{aligned}
& \mathrm{h} \quad=\quad \text { Enthalpy of superheater }(\mathrm{kJ} / \mathrm{kg}) \\
& \mathrm{h}_{\mathrm{f}} \quad=\quad \text { Enthalpy at saturated steam }(\mathrm{kJ} / \mathrm{kg}) \\
& \mathrm{h}_{\mathrm{f}}=\mathrm{m}_{\mathrm{cp}} \Delta \mathrm{T} \quad \text {.......... } \\
& \text { Where, } \\
& \mathrm{m}_{\mathrm{a}}=\text { mass of steam/per } \mathrm{kg} \\
& c_{p}=\text { specific heat of water } \\
& \Delta \mathrm{T}=\text { Difference in temperature in outlet to inlet }
\end{aligned}
$$

\section{Efficiency of Simple Boiler:}

$$
(\eta)=\frac{\text { Heat absorbed or heat output }}{\text { Heat supplied or heat input }}
$$




\section{Heat Input of Tangentially Fired Burner}

Total pulverized coal in primary air:

$\mathrm{B}_{\mathrm{mf}}=(1-\Delta \mathrm{w}) \mathrm{X}\left(\mathrm{B}_{\mathrm{j}}-0.15 \times \mathrm{Z}_{\mathrm{m}} \times \mathrm{B}_{\mathrm{m}}\right) \mathrm{kg} / \mathrm{hr}$

Where,

$\Delta \mathrm{w}=$ Moisture vaporized per $\mathrm{kg}(\mathrm{kg} / \mathrm{kg} \mathrm{PC})$

$\mathrm{B}_{\mathrm{j}} \quad=\quad$ Coal burned $(\mathrm{kg} / \mathrm{hr})$

$\mathrm{Z}_{\mathrm{m}}=$ Number of mills

$\mathrm{B}_{\mathrm{m}}=\quad$ output of the mills $(\mathrm{kJ} / \mathrm{hr})$

Heat needed to heat pulverized coal:

$\mathrm{q}_{1}=\frac{\left(100-\mathrm{W}_{\mathrm{mf}}\right) \times \mathrm{c}_{\mathrm{mf}}\left(\mathrm{T}_{1}^{1}-\mathrm{T}_{\mathrm{mf}}\right)}{100}$

Where,

$\mathrm{W}_{\mathrm{mf}}=$ Moisture content in pulverized coal $(\%)$

$\mathrm{c}_{\mathrm{mf}}=$ Specific heat of pulverized $\operatorname{coal}\left(\mathrm{kJ} / \mathrm{kg}{ }^{\circ} \mathrm{C}\right)$

$\mathrm{T}_{1}{ }^{1}=$ Primary air temperature $\left({ }^{\circ} \mathrm{C}\right)$

$\mathrm{T}_{\mathrm{mf}}=$ temperature of pulverized coal $\left({ }^{\circ} \mathrm{C}\right)$

Heat supplied by primary air and secondary air:

$\mathrm{q}_{2}=\left\{1.285 \times \alpha_{1} \times \mathrm{V}^{\circ} \times \mathrm{r}_{1} \times\left[\left(\mathrm{c}_{\mathrm{pa}} \times \mathrm{T}_{2}\right)-\left(\mathrm{c}_{\mathrm{am}} \times \mathrm{T}_{1}{ }^{1}\right)\right]\right\}+\mathrm{r}_{2}$

Where,

$\alpha_{1}=$ excess air co efficient

$\mathrm{V}^{\circ}=$ theoretical air needed $\left(\mathrm{nm}^{3} / \mathrm{kg}\right)$

$\mathrm{r}_{1}=$ primary air $(\%)$

$\mathrm{c}_{\mathrm{pa}}=$ specific heat of air after mixing $\left(\mathrm{kJ} / \mathrm{kg}^{\circ} \mathrm{C}\right)$

$\mathrm{c}_{\mathrm{am}}=$ Specific heat of air after mixing $\left(\mathrm{kJ} / \mathrm{kg}^{\circ} \mathrm{C}\right)$

$\mathrm{T}_{2}=$ Secondary air temperature $\left({ }^{\circ} \mathrm{C}\right)$

$\mathrm{T}_{1}{ }^{1}=$ primary air temperature $\left({ }^{\circ} \mathrm{C}\right)$

Total heat input of a pulverized coal:

$\sum_{q}=\mathrm{B}_{\mathrm{mf}} \times\left(\mathrm{q}_{1}+\mathrm{q}_{2}\right)$

$\mathrm{B}_{\mathrm{mf}}=$ Total pulverized coal in primary air $(\mathrm{kg} / \mathrm{hr})$

$\mathrm{q}_{1}=$ Heat needed to heat pulverized coal $(\mathrm{kJ} / \mathrm{kg})$

$\mathrm{q}_{2}=\quad$ Heat supplied by primary and secondary air $(\mathrm{kJ} / \mathrm{kg})$

\section{Heat output of Tangential Fired Boiler}

Corresponding enthalpies are finding with the help of feed water temperatures in Moeller chart and steam tables.

Heat absorbed in economizer per $\mathrm{kg}$ of feed water:

$h_{e}=m \times c_{p} \times\left(t_{0}-t_{i}\right)$ 
Where,

$\mathrm{m} \quad=\quad$ Mass of water under consideration $(\mathrm{kg})$

$\mathrm{c}_{\mathrm{p}} \quad=\quad$ Specific heat of water $\left(\mathrm{kg} / \mathrm{kg}^{\circ} \mathrm{C}\right)$

$\mathrm{t}_{0}=$ Temperature of feed water leaving the economizer $\left({ }^{\circ} \mathrm{C}\right)$

$\mathrm{t}_{1}=$ Temperature of feed water entering the economizer $\left({ }^{\circ} \mathrm{C}\right)$

Heat absorbed in boiler per $\mathrm{kg}$ of feed water:

$\mathrm{h}_{\mathrm{b}}=\left(\mathrm{h}_{\mathrm{f}}+x \mathrm{~h}_{\mathrm{fg}}\right)-\mathrm{h}_{\mathrm{e}}[\mathrm{kJ} / \mathrm{hr}]$

Where,

$\mathrm{h}_{\mathrm{f}} \quad=\quad$ Enthalpy of saturated steam $\left(\mathrm{kg} / \mathrm{kg}{ }^{\circ} \mathrm{C}\right)$

$x=$ Dryness fraction

Heat absorbed in Superheater per kg of feed water:

$\mathrm{h}_{\mathrm{s}}=(1-x) \mathrm{h}_{\mathrm{fg}}+\mathrm{c}_{\mathrm{p}}\left(\mathrm{T}_{\mathrm{sup}}-\mathrm{T}_{\mathrm{s}}\right)$

Where,

$\mathrm{c}_{\mathrm{p}}=$ Specific heat at superheated steam $\left(\mathrm{kJ} / \mathrm{kg}{ }^{\circ} \mathrm{C}\right)$

$\mathrm{T}_{\text {sup }}=$ Temperature of steam leaving superheater $\left({ }^{\circ} \mathrm{C}\right)$

$\mathrm{T}_{\mathrm{s}}=$ Temperature of steam entering superheater $\left({ }^{\circ} \mathrm{C}\right)$

Heat absorbed in Reheater by $1 \mathrm{~kg}$ of feed water:

$h_{r}=h_{f}+c_{p}\left(T_{r e h}-T_{R}\right)$

Where,

$\mathrm{T}_{\text {reh }}=$ Temperature of steam leaving the re heater $\left({ }^{\circ} \mathrm{C}\right)$

$\mathrm{T}_{\mathrm{R}}=$ Temperature of steam entering reheater $\left({ }^{\circ} \mathrm{C}\right)$

Total heat output:

$Q_{\text {output }}=h_{e}+h_{b}+h_{s}+h_{r}$

Where,

$\mathrm{h}_{\mathrm{e}}=$ Heat absorbed in Economizer

$\mathrm{h}_{\mathrm{b}}=$ Heat absorbed in Boiler

$\mathrm{h}_{\mathrm{s}}=$ Heat absorbed in Superheater

$\mathrm{h}_{\mathrm{r}}=$ Heat absorbed in Reheater

\section{Heat losses in Tangentially Fired Boiler}

Heat loss due to dry gas:

$\mathrm{q}_{\mathrm{dg}}=$ Dry gas $(\mathrm{kJ} / \mathrm{kg})$ as fired fuel $\mathrm{x} \mathrm{c}_{\mathrm{p}}\left(\mathrm{t}_{\mathrm{gi}}-\mathrm{t}_{\mathrm{ge}}\right)$ 
Where,

$\mathrm{t}_{\mathrm{gi}}=\quad$ Temperature of gas leaving boiler $\left({ }^{\circ} \mathrm{C}\right)$

$\mathrm{t}_{\mathrm{ge}}=$ Temperature of air combustion $\left({ }^{\circ} \mathrm{C}\right)$

$\mathrm{c}_{\mathrm{p}}=$ Specific heat at dry gas $\left(\mathrm{kJ} / \mathrm{kg}^{\circ} \mathrm{C}\right)$

Heat loss due to Moisture:

$\mathrm{q}_{\mathrm{m}}=\frac{\text { moisture }(\%) \mathrm{x}\left(\mathrm{h}_{\mathrm{L}}-\mathrm{h}_{\mathrm{C}}\right)}{100}$

Where,

$\mathrm{h}_{\mathrm{L}}=$ Enthalpy of gas leaving boiler $(\mathrm{kJ} / \mathrm{kg})$

$\mathrm{h}_{\mathrm{C}}=$ Enthalpy of liquid at combustion $(\mathrm{kJ} / \mathrm{kg})$

Heat loss due to Hydrogen for Combustion:

$\mathrm{q}_{\mathrm{H} 2}=9 \mathrm{x} \%$ of Hydrogen $\mathrm{x}\left[\mathrm{h}_{\mathrm{VO}}-\mathrm{h}_{\mathrm{LC}}\right]$

Where,

$\mathrm{h}_{\mathrm{VO}}=$ Enthalpy of gas at output $(\mathrm{kJ} / \mathrm{kg})$

$\mathrm{h}_{\mathrm{LC}}=$ Enthalpy of liquid at combustion $(\mathrm{kJ} / \mathrm{kg})$

Heat loss due to combustive in refuse:

$\mathrm{q}_{\mathrm{ref}}=$ dry refuse $(\%) \times$ Ash in Refuse $(\mathrm{kJ} / \mathrm{kg})$

Where,

Dry refuse $=($ Ash pit + Fly ash $)$

Heat loss due to Radiation $(\mathrm{kJ} / \mathrm{hr})=\mathrm{q}_{\mathrm{r}}$

Total heat losses:

$\mathrm{q}_{\text {losses }}=\left[\mathrm{q}_{\mathrm{dg}}+\mathrm{q}_{\mathrm{m}}+\mathrm{q}_{\mathrm{H} 2}+\mathrm{q}_{\mathrm{ref}}+\mathrm{q}_{\mathrm{r}}\right]$

Where,

$\mathrm{q}_{\mathrm{dg}}=$ Heat loss due to Dry gas $(\mathrm{kJ} / \mathrm{hr})$

$\mathrm{q}_{\mathrm{m}}=$ Heat loss due to Moisture $(\mathrm{kJ} / \mathrm{hr})$

$\mathrm{q}_{\mathrm{H} 2}=$ Heat loss due to Hydrogen $(\mathrm{kJ} / \mathrm{hr})$

$\mathrm{q}_{\mathrm{re}}=$ Heat loss due to Combustion in refuse $(\mathrm{kJ} / \mathrm{hr})$

$\mathrm{q}_{\mathrm{r}}=$ Heat loss due to Radiation $(\mathrm{kJ} / \mathrm{hr})$

\section{Efficiency}

Total heat output of tangential boiler:

qoutput $=$ qinput - qloses

$=\Sigma_{\mathrm{q}}-\mathrm{q}_{\text {loses }}$ 
Total heat input of pulverized coal:

$\Sigma_{\mathrm{q}}=\mathrm{B}_{\mathrm{mf}} \mathrm{X}\left[\mathrm{q}_{1}+\mathrm{q}_{2}\right]$

Total efficiency of tangentially fired boiler:

$\eta_{\mathrm{tb}}=\frac{\mathrm{q}_{\text {output }}}{\Sigma_{\mathrm{q}}}$

$\eta_{\mathrm{tb}}=\frac{\Sigma_{\mathrm{q}}-\mathrm{q}_{\text {loses }}}{\Sigma_{\mathrm{q}}}$

\section{Results and Discussion}

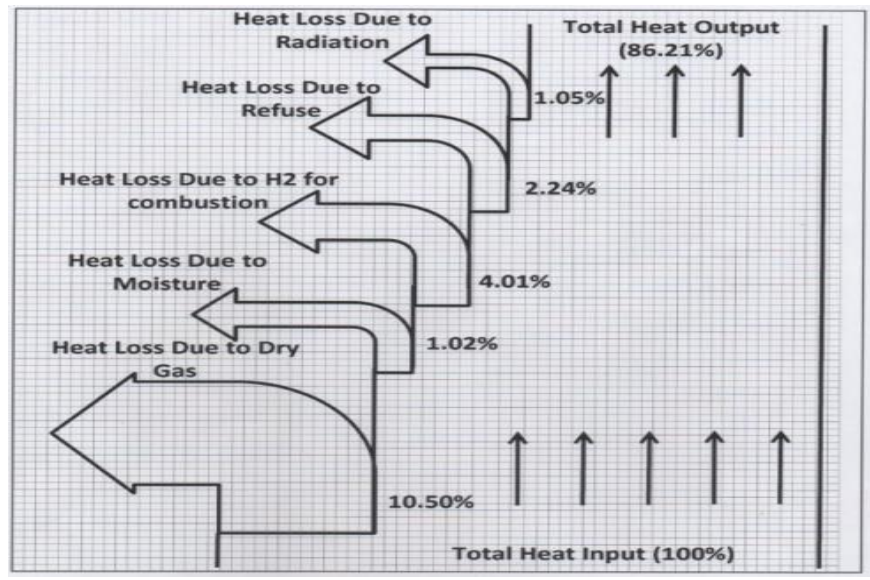

Figure 4: Sankey Diagram for Variation of Total Heat Input to Heat Output and Heat Losses at $10000 \mathrm{~kg} / \mathrm{hr}$ Coal Input

The above fig.04 shows the variation of total heat input in tangential boiler. Temperature increases more in tangentially fired boiler compared to simple boiler. Variation of Coal input at $10000 \mathrm{~kg} / \mathrm{hr}$ expels $1789.26 \mathrm{~kJ} / \mathrm{hr}$ heat losses and $8526.45 \mathrm{~kJ} / \mathrm{hr}$ heat is absorbed.

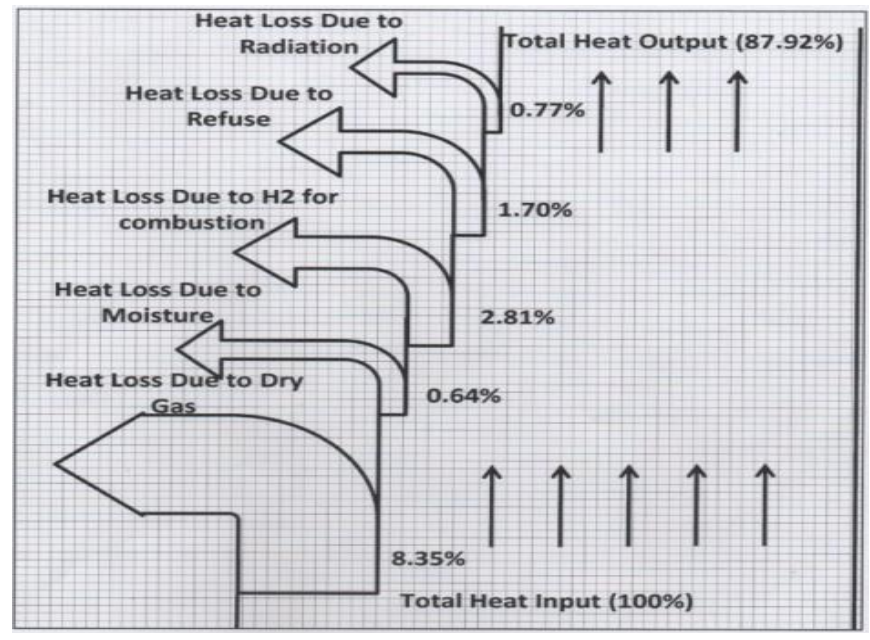

Figure 5: Sankey Diagram for Variation of Total Heat Input to Heat Output and Heat Losses at $10500 \mathrm{~kg} / \mathrm{hr}$ Coal Input 
The above fig. 05 shows the variation of total heat input in tangential boiler. Temperature increases more in tangentially fired boiler compared to simple boiler. Variation of Coal input at $10500 \mathrm{~kg} / \mathrm{hr}$ expels $1689.21 \mathrm{~kJ} / \mathrm{hr}$ heat losses and $10465.18 \mathrm{~kJ} / \mathrm{hr}$ heat is absorbed.

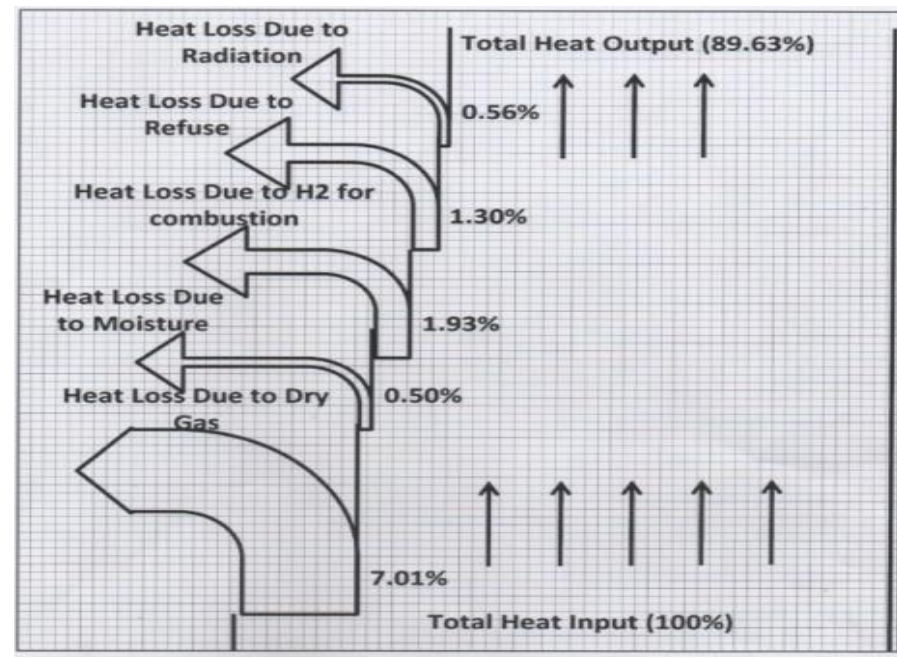

Figure 6: Sankey Diagram for Variation of Total Heat Input to Heat Output and Heat Losses at $11000 \mathrm{~kg} / \mathrm{hr}$ Coal Input

The above fig.06 shows the variation of total heat input in tangential boiler. Temperature increases more in tangentially fired boiler compared to simple boiler. Variation of Coal input at $11000 \mathrm{~kg} / \mathrm{hr}$ expels $1572.61 \mathrm{~kJ} / \mathrm{hr}$ heat losses and $13056.12 \mathrm{~kJ} / \mathrm{hr}$ heat is absorbed.

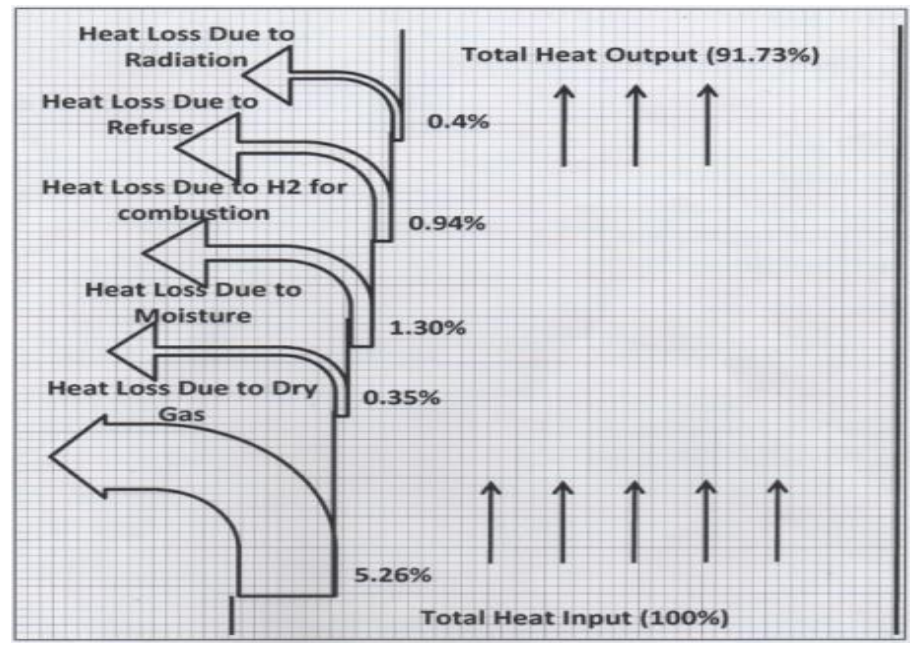

Figure 7: Sankey Diagram for Variation of Total Heat Input to Heat Output and Heat Losses at $11452 \mathrm{~kg} / \mathrm{hr}$ Coal Input

The above fig.07 shows the variation of total heat input in tangential boiler. Temperature increases more in tangentially fired boiler compared to simple boiler. Variation of Coal input at $11452 \mathrm{~kg} / \mathrm{hr}$ expels $1496.21 \mathrm{~kJ} / \mathrm{hr}$ heat losses and $16589.61 \mathrm{~kJ} / \mathrm{hr}$ heat is absorbed. 


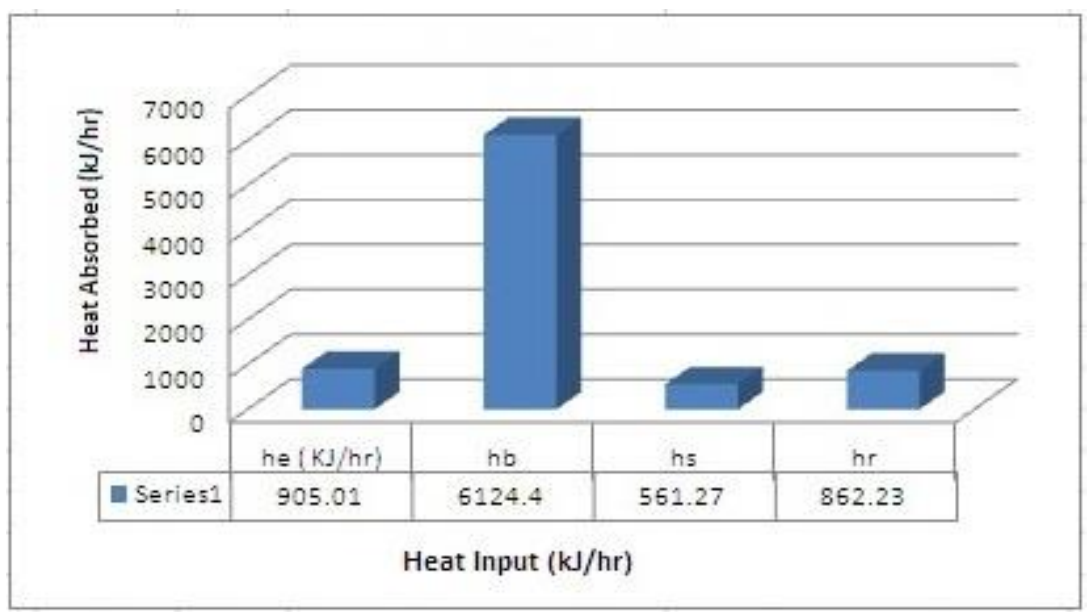

Figure 8:

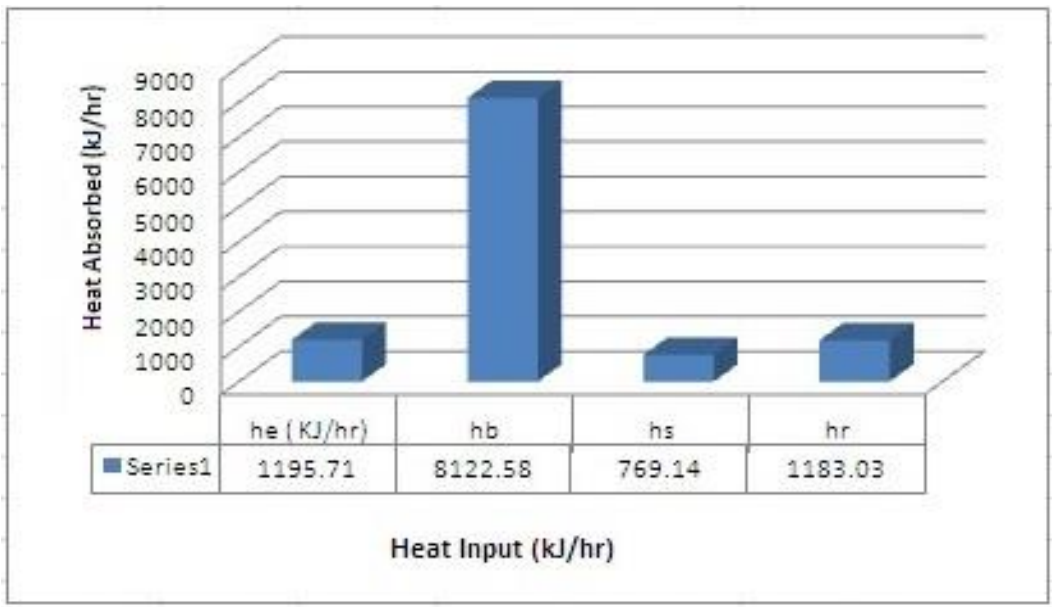

Figure 9:

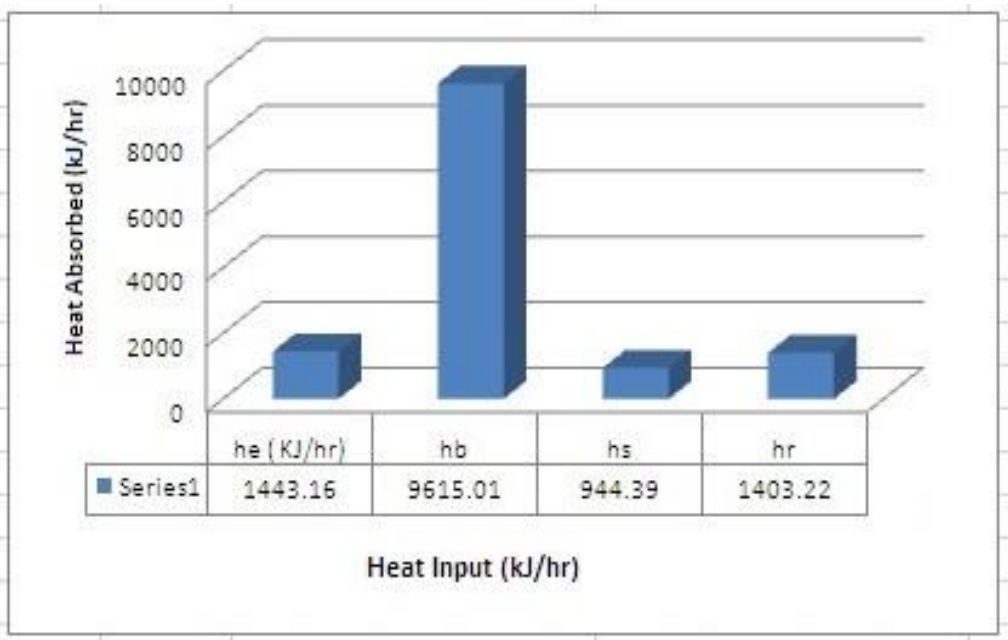

Figure 10: 


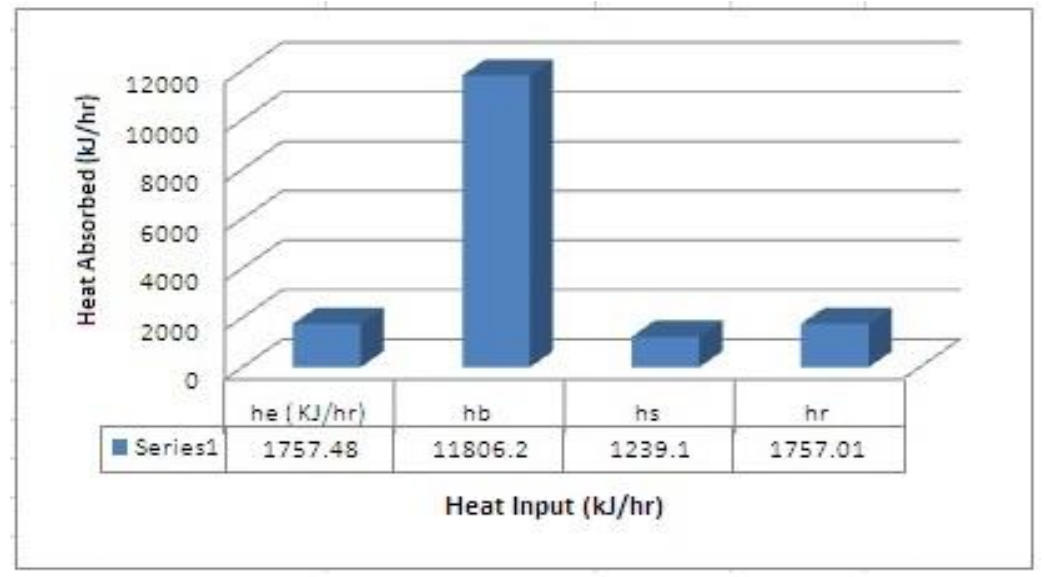

Figure 11:

The above Figures $(08,09,10 \& 11)$ shows the variation of heat absorbed by the economizer, boiler, superheater and reheater with respect to Heat Input supplied by the Tangentially Fired Burner respectively.

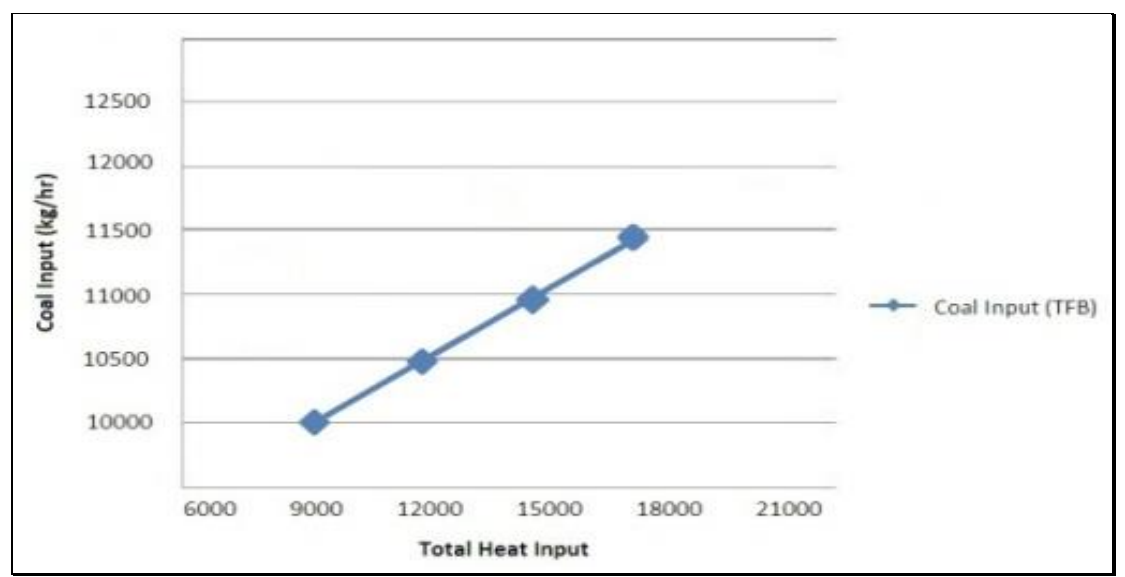

Figure 12: Variation of Coal Input (kg/hr) with Total Heat Input in a Tangentially Fired Boiler

The above fig. 12 gives a variation of Coal input $(\mathrm{kg} / \mathrm{hr})$ with Total Heat Input. It is observed that when Coal input increases, total heat input of Tangentially Fired Boiler also increases.

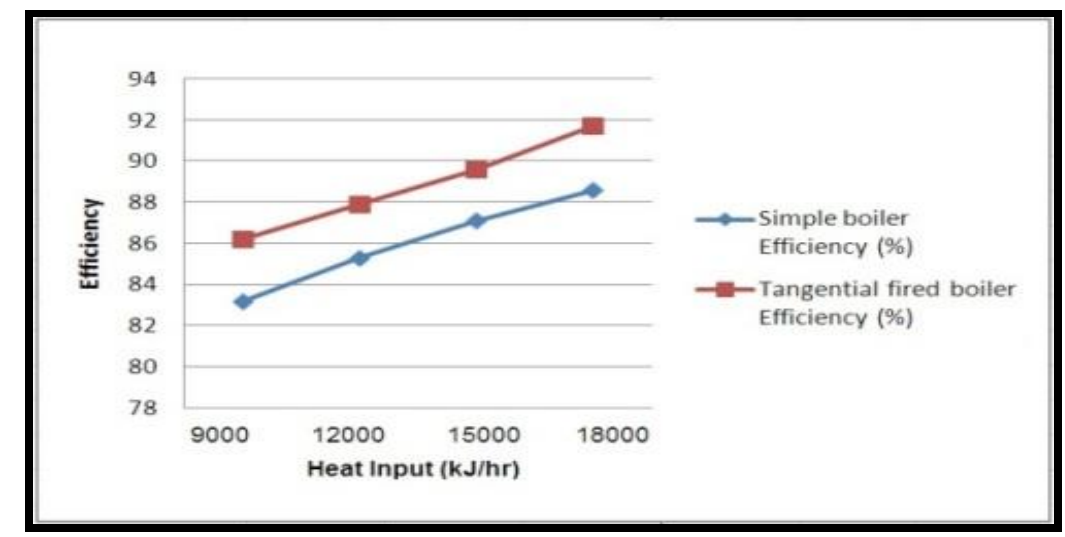

Figure 13: Variation of Efficiency $(\eta)$ with total Heat Input $(\Sigma q)$ 
The above fig.13 shows the variation of Efficiency $(\eta)$ with total Heat supplied $(\Sigma q)$. It is observed that when Heat supplied to the Tangentially Fired Boiler, its efficiency increases more than the Simple Boiler.

\section{Conclusions}

The following conclusions are arrived from the performance analysis of a Tangentially Fired Boiler in Thermal Power Plant.

1) In Tangential Boiler the Coal Input at $10,000 \mathrm{~kg} / \mathrm{hr}$ absorbs $8526.45 \mathrm{~kJ} / \mathrm{hr}$. While coal input at $11452 \mathrm{~kg} / \mathrm{hr}$ absorbs $16589.61 \mathrm{~kJ} / \mathrm{hr}$, which shows an increase of $48.68 \%$

2) The heat absorbed in simple boiler at $9700.12 \mathrm{~kJ} / \mathrm{hr}$ heat input is $8108.60 \mathrm{~kJ} / \mathrm{hr}$, while $16589.61 \mathrm{~kJ} / \mathrm{hr}$ heat is absorbed at heat input of $18085.21 \mathrm{~kJ} / \mathrm{hr}$ in a tangential boiler, thus shows an increase of $48.21 \%$.

3) The efficiency of simple boiler is $83.19 \%$ to an increase of $91.73 \%$ in a tangentially fired boiler, this shows an increase of $8.54 \%$.

4) Finally the input parameters of tangentially fired boiler such as coal input, inlet temperature, excess amount of primary air and secondary air expels the output parameters of net heat output and thermal efficiency respectively.

\section{Acknowledgement}

We, authors express gratitude to all the anonymous reviewers for their affirmative annotations among our paper. Thanks to every reviewers for their affirmative annotations among our paper. Thanks to every reviewer for reviewing our paper and give valuable suggestions.

\section{References}

[1] G.R. Offen, J.P.Kesserburg, K. Lee G. Poe., control of particulate matter from Tangential fired burners, Environmental protection agency, Reduction of $\mathrm{Co}_{2}$ Emissions, North Carolina, pp.7-1 to 7-27, 2015

[2] Mr.Ashish Fande and P.V.Joshi, Practical boiler operation in the Power Plant, Applied Science and Engineering, $4^{\text {th }}$ Edition, PHI Learning Private Limited, Part-IV, PP-101-126, 2015.

[3] Cristians V.da Silva, Study the analysis of tangentially fired burners, Reduction of $\mathrm{Co}_{2}$ emissions controlled by the burners, consolidated Edison Company of New York, Vol.4; No.5 PP 157-261, 2004.

[4] B.F.Piper, KVB, in C., New York State Energy Research and Development Authority, Combustion of Bituminous Coal in Pulverized State and liquids in tangential fired boiler, Vol.43, No.16, pp.1012-10 22, 2000.

[5] Infante Ferreira, Carlos.A, Applied thermal Engineering, Utility of tangential boilers, their Design construction and Management, New Age publishers, Vol.IV.

[6] V. Vara Lakshmi and P.S. Kishore, "Thermal Efficiency of Pulverized Fuel Boiler", publisehd in Internatinoal Advanced Research Journal in Sciencey, Engineering \& Technology, Vol.2, No.1 PP.45-49, Jan., 2015.

[7] Haiying Qi, Bo Zhao, Ken Gregory, Experimental investigation on gas flow in a model of tangentially fired boiler, A Options for limiting Carbondioxide Vol.18, pp. 14-17, 2006.

[8] Su Cheng-dong, Tang Xu, W.T. Reid, Research on emission characteristics on axial compression, Internal deposits of Tangential boilders, 38(AO I):12-18, pp.44-52, 2013. 
[9] M. Praveen, P.S. Kishore, "Effectiveness of Rotary Air Preheater in a Thermal Power Plant", International Journal of Scientific Engineering and Technology, Vol.5, No.12, PP. 526-531, Dec. 2016.

[10] Y.K. Rao, P. Chattopadhyay, Stoichiometri and Thermodynamic processes, Operation in tangentially fired boiler, M.C.Graw Hill Education, Pvt. Limited, $3^{\text {rd }}$, Edition, pp.119-127, 2013.

[11] C.S.Rao, Environmental pollution and control Engineering, New Age international publishers, $2^{\text {nd }}$ Edition, pp.137-156, 2007.

[12] Louis Jestin, Cenkefa, Prabir Basu, Boilers and burners, its Design and theory, Mechanical Engineering Series, Spring Publishers, $1^{\text {st }}$ Edition, Vol.III, pp.112-122, 2001.

[13] R.K.Rajput, Thermal Engineering, 8 ${ }^{\text {th }}$ Edition, Lakshmi Publications Pvt. Ltd. pp.592-608, 2010.

[14] Thomos shakre, Mahallawy. Conventional fossil fuel Power Plant during combustion process in tangentially firing system, International Journal Engineering, Vol.3, pp.101-116, Feb. 2015.

[15] Robert E. Hall, Saven Andersson, Khatri, Emissions and performance of boilers in the combustion process, International Journal, Engineering Issue 4, Volume 9, pp. 551-563, 2010.

[16] K. Abhinash, performance of a Tangentially Fired Boiler in a thermal power plant, M.Tech Thesis, Andhra University, 2018.

\footnotetext{
*Corresponding author.

E-mail address: koiladaabhinash@ gmail.com
} 